\title{
THE CHRISTIAN CHURCH AND THE QUEST FOR CULTURAL REVIVAL IN NIGERIA
}

\author{
Kanayo Louis Nwadialor \\ doi: http://dx.doi.org/10.4314/og.v8i1.6
}

\section{Introduction}

Culture is a means of communication and a label of identity. However, there is this general belief in the western world that Africa has no past, and at best that African culture has nothing to write home about. According to Ejiofor (1984) "for too long, the colour, black which is ours, has been associated with something deadly, sinister, wicked, hateful, dismal and even devilish" (p. 13).

For us in Nigeria, 1960 was our year of destiny when the federation of Nigeria became politically independent, but the political connection with Britain was only at the points of contacts between the West and the indigenous peoples of Nigeria, Western religion and value system, and of course, the whole apparatus of Western culture had for long engaged the native cultures in a mortal combat. It hardly occurred to the Western pioneers in Nigeria that the indigenous peoples had cultures of their own, which needed to be treated with respect. These pioneers no sooner they came than they proceeded to conquer the culture of the people. (Nduka,1975). It however, augurs well for the future of Nigeria that her indigenous missionaries and early converts to Christianity had devoted a good deal of attention to the study of the consequence of culture contacts aimed at re-awakening the suppressed but extant elements of our cultural heritage. It was therefore, the time for a less spectacular but far more tenacious struggle for our cultural emancipation from the shackles of colonialism. The voice of Ejiofor (1984) echoed the general yearnings of the pioneer indigenous missionaries that, a serious look should be taken at our culture to reconstruct and rehabilitate it, and reconcile it with the realities of present day Nigeria, Africa and the black world. Meanwhile, the cultural revival does not mean a summons to return to the past. Indeed, much of our past are dead and should be allowed to rest for eternity. More so, a new religion had come into being and makes it a sin for the revival 
of certain elements hitherto practiced. But much of it was very much alive, despite all appearances to the contrary. What was suggested was that there should be a more discriminate blending of foreign cultural elements with the indigenous cultural heritage. These pages, which are the fruits of what may be considered an age long struggle for cultural emancipation, are offered as an analytical reflection on topical elements and aspects of the evolving culture of the Nigerian peoples against Christian background. It was the age in which Nigerian peoples find themselves in the grips of cultural transformation after many decades of colonialism and cultural clash with the pressures and hangovers of neo-colonialism. It is the awareness of this task by the church in enabling the Nigerian man to come into his own and escape being a stooge shaken by the winds of foreign cultures and institutions - all in the name of Christianity and civilization - that is the thrust of this paper.

\section{Culture: Its Concepts and Perspectives}

Cultures can be defined as a body of stored knowledge, characteristic way of thinking and feeling, attitudes, goals and ideas. Ejiofor (1984) had defined culture "as a mass of behaviour that human beings in any society learn from their elders and pass on to the younger generation" (p. 18). It is an organized group of learned responses characteristic of a particular society. According to Stark (1996) "Culture is the sum total of human creations - intellectual, technical, artistic, physical and moral. Culture is the complex pattern of living that directs human social life. The things each generation must and to which they eventually may add" ( $p$.43). Culture interprets human surroundings and give them improved meaning which allows us express ourselves, language, religion, science, and art, notion of right and wrong explanation of the meaning of life these are all parts of the cultural systems of a society. Uche (2009) noted that "Culture remains everything acquired by a human being that is not physically inherited, but remains a social property passed on through learning and teaching from generation to generation" ( $\mathrm{p}$. 156). However, it was Tylor (1970) who gave a relatively comprehensive definition of culture when he asserted that "culture is that complex whole which includes knowledge, belief, art, moral, 
law, custom, and any other capabilities and habits acquired by man as a member of society" (p. 20).

To recapitulate as it were all the essential ingredients of the preceding definitions, Iwe (1985) submitted that:

Culture therefore refers to the way of life of a people - a way of life that reflects their distinctive genius and spirit, their fundamental character or ethos, their value orientation, world-view, institutions and achievement in the various fields of human endeavour - legal and literary, artistic and scientific, religious philosophical and technological. (p .17).

In brief therefore, culture is an aggregate concept fundamentally characterized by the distinctive spirit, way of life, device for living and attainments of a people.

With regard to the perspectives of culture, two fundamental and mutually complementary aspects of culture could be identified, the spiritual aspect of culture on one hand, and the visible, external symbols and manifestation of culture on the other hand. The spirit is the basic or the core aspect of a culture. The spirit is the essence of a culture that is ever constant and surviving all processes of acculturation, while the body is the expression of the same culture that is adaptable and accidental, which can be subject to acculturation, culture fertilization and cultural borrowing, and to the impact of the vagaries of circumstances of time and space, place and personalities, events and movements. Iwe (1985) put it this way:

The spirit and fundamental institutions of a culture are immutable, a social heritage, integrating and coherent in character, comprehensive in the scope of sway over its members, and essentially focused on values, vision and interpretation of life ideas and aspirations. While the body and material elements of a culture are essentially mutable and volatile, man- 
made, easily modifiable, and ever subject to circumstantial changes and expediencies. (p .85).

When therefore a serious and functional consideration of culture is undertaken, it is the spirit and basic institutions that matter and count. We here in Nigeria have therefore a culture which still persists in spite of the impact and incursions of white colonialism, neo-colonialism and Western structures. When we therefore talk about cultural revival, it is this core aspect of the culture of the Nigerian peoples that forms our focus of attention.

\section{Cultural decay in Nigeria: Causes and effects}

The cultural heritage of the Nigerian peoples had in the past been severely dealt with that it became doubtful whether much of the good values in Nigerian cultural heritage could be rehabilitated. The reasons for this cultural decay range from slavery and slave trade, colonialism and imperialism, illiteracy, interiority complex, and so on.

\section{Slavery and Slave Trade}

Nothing can be more humiliating to a people than slavery. According to Ryder (1999):

The first cargoes of slaves carried from Nigerian shores in European ships were destined not for the Americans but for the Gold Coast were Portuguese traders seeking gold found necessary to offer slaves as well as cloth and metal wares that brought gold to the Coast. It was soon discovered that slaves could be obtained quite close at hand in the rivers west of the Niger Delta, and by 1440 it had become a regular practice for one or two Portuguese caravans to enter these rivers each year in search of slaves. ( $p$. 237).

Nigerian people have for too long maintained a servant master relationship with other peoples. At first it was the Muslim Arabs who raided black villages and carried black youths Trans Sahara into 
slavery. Later on in the sixteenth century, the Arab slave drivers were joined on a much more massive scale by Christian Europe in transporting the cream of African youths into the Western world. How many blacks were so carried away cannot be ascertained for sure. Ejiofor (1984) maintained that historians have not succeeded yet in giving us an exact number of black people who fell victims of slave trade. They may never succeed. Such victims include those who died in the inter village and town wars - instigated by the slave traders; those who died on the march from the point of capture in the homeland to the point of shipment on the coast, those who died of starvation, epidemic, suffocation, brutality and humiliation in the slave ships, those who died of the booting and the kicking, etc. It is important to note that during that period, premium was placed on culture substitution - displacing African languages with European languages, palm wine with beer, African clothing and food with European suits and food, African religion with foreign religions and ultimately displacing African way of life and value system with that of the Europeans.

\section{Colonialism and Imperialism}

Just as the time the slave trade was dying and the Nigerian man once more had an opportunity of reconstructing his bearing, Western imperialism came to further shatter the fledging value systems, and so further distort the cultural profile of the peoples of Nigeria. The combine forces of these two exogenous factors shook the self confidence of the Nigerian peoples to its very foundation, and as Ejiofor (1984) put it:

In this way, Igbo culture in its virgin form was in a sense raped by the slave traders and abducted by Western civilization. It is difficult to say for sure which of these made the greater impact on Igbo culture. But whichever it was, the net effect of the operation of these forces was a decay of the traditional moral code, and the creation of a cultural vacuum within which individual Igbo operated in 
their relationship with one another, the community and the society. (p. 70).

From 1898, the British government sought to establish and maintain a colonial state in Nigeria. This process of colonialism involved a number of measures including the subjugation of certain visible cultural heritage and the removal of all opposition from the territory later known as Nigeria. A succession of British officials used coercion and diplomacy in former northern and southern Nigeria to reduce indigenous opposition to a minimum. Tamuno (1999) posited that:

Instances of relentlessness under increasing colonial rule were forcibly suppressed with the assistance of the military and police resources at the disposal of the government. British rule in Nigeria was in the final analysis buttressed by force or by the threat of using it. (p. 393).

Ancient rulers, as well as other individuals and organizations, made vein attempts to stem the tide of Western imperialism. It was a sorry situation of a cultural struggle between the literate and technically advanced West and the largely pre-literate and pre-technical peoples of Nigeria. In this context, culture is used, as some anthropologists suggested, embracing not only a people's art, music and literature, but also their science and technology, commerce and political organization, philosophy and religion, all the ideas and values implicit and explicit, which permeate the society and bind its people into a recognizable unit. Viewed broadly from this standpoint, Western culture is a unit vis-à-vis the culture or cultures of the indigenous people of Nigeria (Nduka, 1975).

\section{Illiteracy}

Few experiences can be more destructive to, and disruptive of sacred institutions and value systems like illiteracy. Education is certainly one of the major factors in preserving the cultural heritage of a 
people. Though oral tradition and certain other cultural practices were used by African fore fathers in the past to pass on our culture from one generation to the other, yet Europeans came to Africa and concluded that Africans were people without culture and history on the account of the absence of any documented evidence of our heritage. Illiteracy further made the Nigerian man to begin to see everything good with the white man's culture at the expense of his own culture and value systems. The effect was an untold decay of our cultural heritage in the face of the onslaught of western structures.

\section{Inferiority complex}

Few handicaps can make the memory so short, and act as a drag on the inventive spirit like interiority complex. It is ironical that while leading in the fight against the white colonialism, the Nigerian man still identifies himself most intimately with the culture of the white man - he is fighting. Perhaps nowhere else in Africa are the white man clothing style, eating habits, Medicare, mode of worship, language and educational system are as popular as they are in Nigeria. In very few other places in Africa has a peaceful change been as quick as the transition from pre-colonial to post colonial Nigerian life style. The break with the past is almost total. In the process, some of the noble value systems of the Nigerian peoples were almost swept away to the detriment of the society.

\section{Factors that Gave Rise to Cultural Revival in the Church}

Christianity needed to be firmly rooted in the culture of the Nigerian peoples. The fact remains that unless the church is firmly planted in the cultural soil of the people, it is on the quick sand of instability and in danger of losing its credibility, and hold on that culture. It is for this reason that Hastings (1967) had noted that "the failure of the Christian churches to get rooted in indigenous culture was mainly responsible for the withering of these churches in the Congo and Benin Kingdom between the $16^{\text {th }}$ and the $18^{\text {th }}$ centuries". (p. 53). In the same vein, Iwe (1985) opined that a religion which does not take 
cognizance of, and derive some inspiration from the socio-cultural and historical matrices of a people is bound to create more problems than it sets out to solve, having regards to the stresses attendant upon the forces of cultural heritage.

The sharp division between Western missionary Christianity and African culture tended to lead to a dilemma in the experience of many African Christians. More frequently the adoption of the new faith produced African Christians with foot in two worlds who found it difficult to reconcile their sense of belonging to African heritage with Western form of Christianity. Arch-bishop Desmond Tutu gave expression of this dilemma, as cited in Parrat (1997) that "Africans suffer from a form of religious schizophrenia because of the struggle between their Christianity and their Africanness" (p. 4). Consequently, African Christians began to address themselves to the question as to how they can be Christians and Africans.

Meanwhile the rediscovery of the values of our traditional cultural heritage led some Nigerian early Christian converts and indeed African theologians into a movement that was called inculturation movement. It was a movement that is aimed at bringing into the service of Christ those qualities of characters that had made Africa great and had ensured stability and moral sanctity in African societies before the advent of Christianity. For many Nigerian Christians all these led to a conclusion that our rich cultural heritage and present situation could no longer simply be dismissed as "Pagan", but needed to be taken seriously and somehow related to the truths of the Christian faith.

\section{The Church and Cultural Revival in Nigeria}

One might be tempted to think or imagine that the church is irrelevant to our cultural regeneration. However, it must be born in mind that religion, and indeed Christianity is an essential and inseparable aspect of human existence as culture itself. Religion and culture are twin, essential, inseparable, and interdependent aspects of human life. Religion and culture are so intimately related and connected that in reality it is impossible for a society to have a culture without religion or religion without culture (Iwe, 1985). No culture has appeared or developed except together with religion. In 
our local Nigerian context, the church has contributed in sundry ways in effecting a regeneration of our indigenous cultural heritage.

\section{The Church and Western Education}

Much of the recent past comes to life as we study the history of formal education as introduced into Nigeria by the missionaries. Western education is probably the one cultural innovation that has had, and is likely to have, the most far-reaching effects on the indigenous culture. In a relatively heterogeneous cultural unit like Nigeria, education may be regarded as the process of transmitting the people's culture, at least part of it, from one generation to the next. Though before the arrival of the missionaries the Nigerian peoples had their own systems of educating the younger members of the society, however, with the coming of the missionaries there was the introduction of a new element, Western formal education. Then arose the problem as to which culture should be transmitted from one generation to the next. The European pioneers of Western education in Nigeria had no doubt as to which culture should be preserved or transmitted. They laboured under certain preconceptions which severely limited their vision, until new happenings and fresh ideas (the Christian teaching of equality of all men) made them have second thoughts. Indeed, there is a lot that the church should be proud of when the full story of her enterprise in Nigeria comes to be told. No doubt the lion's share of the praise in the educational sphere will go to the church. The Christian missionaries who were the pioneers of Western education in Nigeria were also responsible for the running of the great majority of the schools in Nigeria. It was the first set of Nigerian elites, the product of the mission schools, who made the first determined attempts to resuscitate the cultural heritage of the Nigerian peoples.

\section{The Role of Enlightenment and Cultural Appreciation}

Closely allied to its role in Western education was the church's contribution through enlightenment and cultural appreciation. The church guided the Nigerian peoples by exhortation and programmed measures of action in the serious task of wiping out mass ignorance 
from the face of our land. The church had the duty to encourage our people to dispose themselves to the benefits from the educationally and culturally revolutionary measures.

There were so many man-made disabilities and miseries arising from simple ignorance such as ill planned families and irresponsible conception and reproductive habits, protein deficient diets, environmental blindness and life in filthy surroundings, poor eating habits, and so on, which the church had helped to stamp out or at least reduced to a very low level through enlightenment and demolition of popular ignorance, prejudice, fear and superstition.

Our culture has also got magnanimous values such as respect for human life and the liberty of man, love of truth and honesty, social solidarity, belief in retribution and reward after death etc. These basic elements of our cultural values were appreciated and enhanced by the Christian religion.

\section{Nationalist Spirit and the Rise of Independent African Churches}

Of all the agents of imperialism it was the missionary who has the most revolutionary impact of the Nigerian peoples. It was an enterprise which was to result in a certain degree of mental revolution and which, eventually gave rise to a seeming social revolution with the rejection of certain elements of Western cultures that has no relevance to the value systems of the Nigerian peoples.

The exponents of Nigerian cultural revival were mainly individuals who had refused to give up their territories without struggle and who revolted against the very Western culture that had nourished them, because they were denied a respectable place within that same culture because of their race. These group of Nigerians were led by men such as Edward Blyden, Bishop James Johnson, Mojola Agbebi, John Payne Jackson, William Bright Davies to mention a few. They were strongly opposed to the attempts of Christian missions to denationalize Africans and were never weary of advocating a conscious rejection of those aspects of Western culture which seemed to them to be of no value to Africans and calling on them to drink deep from the fountain of their culture. There were also exponents and founders of the indigenous African churches which Ayandele (1970) described as the first concrete manifestations of cultural nationalism in Nigeria. Some of them 
demonstrated their rejection of Western culture in practical terms by dropping their English names and dresses. For examples, David Vincent became Majola Agbebi, George William Johnson became Osholake Tejumade, and Francis Ibiam became Akanu Ibiam. The Rev. James Johnson who did not change his own name demonstrated his rejection of Western culture by refusing to baptize any child with an English name.

\section{The Church and the Development of Indigenous Languages}

The missionaries believed, and rightly so that it would be impossible to convey the gospel message effectively to any people unless the evangelist himself was able, not only to master the local language of the people but to understand and appreciate their thought and value systems. For this, the missionaries devoted considerable attention to the study of the indigenous languages, and this was one of the areas in which they made their greatest contributions to the cultural revival of the Nigerian peoples. According to Tasie (1996) "The study of Igbo language, as far as evidence shows, was begun by John F. Schon, the German linguist and missionary, who for his linguistic achievements was in 1884 to receive the D.D. Oxford. He had reduced Igbo to writing in 1841 for the use of the famous Niger expedition of that year. When Schon retired from West Africa, Samuel Ajayi Crowther continued the investigation from 1854 1857 in Sierra Leone; and with the help of his African assistants, Crowther discovered what came to be regarded as the standard Igbo, or the Igbo dialect.

The point we are making here is that the language of a people cannot be taken in isolation, but as part of the vehicle for expressing the culture and thought system of the people. Thus, the claim by Taylor and his colleagues as the pioneers in the study of Igbo language does not only mean a mastery of the grammar and syntax of the language. It involves much more than that. In effect, it entails the mastery of the culture and thought systems of the Igbo people and the sensitization of the people to breath from their cultural fountain and save it from extinction from the onslaught of Western culture and civilization. 
Taylor appreciated the fact that the Christian religion was not being introduced into a vacuum, but upon some already existing cultural situation, especially the traditional religious culture. It was apparently in view of this awareness that he set his mind to find out for himself and for the benefit of the Christian missionary enterprise as well, all that he could about the Igbo people. In doing so, he took stock of everything that he could possibly reckon with:

About the Ozo title, Taylor, relying on his own personal researches had, as early as 1862 , concluded that it is essentially an affair belonging to the people's social culture, that it was a way of distinguishing one's status in the society, for which Taylor, therefore, saw nothing essentially wrong or sinful about Christians taking the Ozo title to mark their status in society. (Tasie,1996:68).

\section{The Church and the Purification of Some elements of our Culture}

It is to be noted that not every aspect of a culture is good or acceptable. There could be some elements of its institutions and practices which if allowed persisting for a long time would stultify and degrade that culture. In our culture there are a few of such elements. To this, Ejiofor (1984) observed that the culture of our fathers is not perfect. Some should therefore be abandoned. It is for this reason that the church did not advocate a totalistic approach to cultural revival, which is a wholesome exhumation and re-animation of the cultures of our fathers. It is in this regard that the church had played a purifying role in our cultural regeneration. The church has done much to integrate into modern life only what seems valuable from our cultural past.

Certain bad customs that were frowned at and fought against by the church included such things as human sacrifice, Osu caste system, killing of twins, denial of rights to women, secret societies and so on. These were most mischievous and pernicious heritage devised and bequeathed to us by our fore bearers through fear and innocent ignorance. It is therefore these culturally purifying truths that the church has fearlessly and ceaselessly striven to impress on 
the minds and will of our people. It is by putting up a stiff fight against these aspects of our social heritage which are neither good nor honest nor authentic that the church had contributed in our cultural evolution and freeing it from its humiliating internal shackles and elevated it to acceptable standard and dignity.

\section{The Church in Defense of Indigenous Culture}

It is now a matter of common knowledge that our culture is battling desperately against foreign-inspired cultural cancer, such as bribery and graft, bureaucracy and nepotism and the injustice of confidential report, denial of merited promotions, authoritarianism and arrogance in power, mamonism or the worship of money, religious discrimination and fanaticism, leadership crisis, and lack of compassion for the common man (Iwe, 1985). All the above mentioned symptoms of cultural malaise and disorder are foreign to the fundamental values of our culture. It is true that it is difficult for the modern man to capture the true cultural value of the Nigerian peoples in its pristine form. For about three hundred years her territory was raided by European agents for slavery and imperialism and the debasing effects of these raids on the culture of the Nigerian peoples can best be imagined. Howbeit, there is substance in the saying that Christianity brought more blessings than curses. This is particularly true in relation to our cultural regeneration because Christianity does not in any way accommodate human debasement. It is to the credit of the church that she was in the fore front of the struggle that saw the abolition of the obnoxious trade in human beings which the early European contact with Nigeria, and indeed Africa, had introduced. To defend our culture against all these symptoms of social morbidity is the task which the church had diligently and courageously addresses.

Closely allied with the defense was the church's effort to patronize our culture. The salient points of our cultural values are not in doubt and they are distilled and preserved in our proverbs, idioms and institutions. The sense of truth and liberty is very dear to our culture. The church has therefore fed our people with the truth, while it has also expounded the implications of the liberty of the 
people of God. In this regard the church has exposed our people to the fact that liberty denotes not merely freedom from bodily restraints but also the right of the individual to engage in any of the common occupation of life, to acquire useful knowledge, to worship God according to the dictates of his conscience.

Furthermore, the church has produced such spiritual churches as the Aladura, the Eternal Sacred Order of Cherubim and Seraphim, the Healing churches and prayer houses whose liturgies have found a strong parallel with the traditional African cosmologies. Ejiofor (1984) added that "The Nigerian Methodist church adapted by creating the patriarchate, traditional artifacts like gongs, drums, Ikoro etc, which were branded as paganism by early missionaries have now been re-introduced into orthodox Christian churches including the Catholic Church". (p. 54). The Ozo title has fought its own battle for survival and has emerged un-vanquished.

\section{Conclusion}

Christianity in its various institutional and social form and manifestations is a human and moral, spiritual and cultural force to be reckoned with. As a religion its claims are both human and divine. In view of its human character, Christianity has, in the course of human history demonstrated itself as the custodian and promoter of human values as well as a preserver of a people's cultural heritage. Iwe (1985) rightly noted that there is sufficient historical evidence to justify this claim when he said that:

It is to be remembered that Christianity had a purifying and humanizing impact on the pagan and imperialistic vices and violence of the ancient Roman Empire. In the dark ages of the $8^{\text {th }}$ and $9^{\text {th }}$ centuries, Christianity stood singularly firm in the West as the sole symbol of light and guidance and as the pledge of brighter future. (p. 29).

In the same vein, the advent and progress of the European encounter with the Nigerian peoples did not found the presence of Christianity entirely wanting. Christianity and some Christian elements stood implacably against the inhuman exploitation and nefarious nature and consequences of the slave trade of the $19^{\text {th }}-20^{\text {th }}$ centuries. 
Christian crusaders and missionaries made strenuous and fruitful efforts which contributed in freeing our cultural heritage from its humiliating internal shackles and elevated it to acceptable standard and dignity. There is, therefore, an abundance of historical evidence to substantiate the role claim of Christianity as the custodian and promoter of human values. It would therefore not be a wild claim to say that the cultural contribution of Christianity were the historical pre-requisites for the Nigerian renaissance and for the dawn of the modern Nigeria. Our special contention here is that there is still a strong need for Christianity to continue its traditional role of being the agent of human values and cultural revival and enrichment here in Nigeria. It is for this reason that Iwe (1985) had argued that our developing African scene exhibits multifarious forces - domestic, ethical, cultural, religious, social, political, national and international - which militate against the realization of unquestionable human values. Against these dehumanizing and degrading forces the resources of Christianity require immediate mobilization and effective deployment. 


\section{References}

Ayandale, E.A. (1970). Holy Johnson: Pioneer of Nigerians nationalism 1836 - 1917. London: Frank Cass.

Ejiofor, P.N.O. (1984). Cultural revival in Igboland. Onitsha: University publishing.

Hastings, A.C. (1967). Church and mission in modern Africa. London: Burns and Oaths.

Iwe, N.S.S. (1985). Christianity and culture in Africa. Onitsha: University Publishing.

Nduka, O.A. (1975). Western education and the Nigerian cultural background. Ibadan: Oxford University.

Parrat, J. (1997). Early Christianity in Africa. Reader in African Christian theology. London: SPCK.

Ryder, A.F.C. (1999). The trans-Atlantic slave trade. In O. Ikime (Ed.). Groundwork of Nigerian history (pp.236-246). Ibadan: Heinemann.

Stark, R. (1996). Sociology. Albany: Wordsworth.

Tamuno, T.M. (1999). British colonial administration in Nigeria in the twentieth century. In O. Ikime (Ed.). Groundwork of Nigerian history (pp.393-409). Ibadan: Heinemann.

Tasie, G.O.M. (1996). John Christopher Taylor, missionary strategist and pioneer Igbo nationalist: A biographical note. In S.N. Adiele (Ed.). The Niger Mission: Origin, growth and impact 1857 - 1995 (pp.53 - 79). Aba: Isaeco.

Uche, O.O.C. (2009). Religion in the Nigerian culture. In N. Okediadi, O.O.C. Uche \& S. Okeke (Eds.). Themes in Nigerian peoples and culture (pp. 150 - 167). Enugu: John Jacobs. 